\title{
Particulate Pollution in Korhogo and Abidjan (Cote d'Ivoire) during the Dry Season
}

Aerosol and Air Quality Research

\section{OPEN ACCESS}

Received: May 6, 2020

Revised: August 27, 2020

Accepted: October 14, 2020

${ }^{*}$ Corresponding Author: gnkonans@gmail.com

\section{Publisher:}

Taiwan Association for Aerosol Research

ISSN: $1680-8584$ print

ISSN: 2071-1409 online

Copyright: The Author(s). This is an open access article distributed under the terms of the Creative Commons Attribution License (CC BY 4.0), which permits unrestricted use, distribution, and reproduction in any medium, provided the original author and source are cited.

\author{
Sylvain Gnamien ${ }^{1,2^{*}}$, Véronique Yoboué ${ }^{1}$, Cathy Liousse ${ }^{2}$, Money Ossohou ${ }^{1}$, \\ Sékou Keita ${ }^{3}$, Julien Bahino ${ }^{1}$, Silué Siélée ${ }^{3}$, Lamine Diaby ${ }^{1}$ \\ ${ }^{1}$ Laboratoire des Sciences de la Matière, de l'Environnement et de l'énergie Solaire, Université \\ Félix Houphouët-Boigny, Abidjan BPV 34, Côte d'Ivoire \\ ${ }^{2}$ Laboratoire d'Aérologie, CNRS, Toulouse, France \\ ${ }^{3}$ Université Péléforo Gon Coulibaly, Korhogo, Côte d'Ivoire
}

\section{ABSTRACT}

Particulate pollution in West African cities seriously impacts public human health. Assessing the levels of pollution to which populations are exposed is problematic, as to date very few countries in Africa have an air quality monitoring network in place. However, given the specific anthropogenic sources present in West African countries and the increase in their projected emissions in the coming years if no regulations are put in place, solutions must be found. This study evaluates with a simple existing methodology particulate air pollution in two West African cities (Korhogo and Abidjan in Cote d'Ivoire) which have different population practices and local meteorology.

From two measurement campaigns at about ten sites during the dry season and using the inverse distance-weighted interpolation method, maps of spatial variation in $\mathrm{PM}_{10}$ and $\mathrm{PM}_{2.5}$ concentrations are obtained at the scale of each of these cities, which provide a snapshot of the concentration levels to which populations are actually exposed. The results of this study showed that populations in low- and middle-income areas are exposed to higher concentrations than those in high-income areas. The analysis of the relative contribution of fine particles to coarse particles shows that $\mathrm{PM}_{2.5}$ contributes to $\mathrm{PM}_{10}$ at less than $40 \%$ in Korhogo but more than $50 \%$ in Abidjan. Daily average concentrations of $\mathrm{PM}_{2.5}$ are all above WHO standards, and are 2 to 8 times higher in Korhogo, while in Abidjan they are up to 4 times higher. The daily profiles of the mean hourly concentrations of the sites are similar across all sites in Korhogo, while in Abidjan, that of some sites show some differences.

This study, by the methodology used, offers an opportunity for different research teams to assess at lower cost the population's exposure levels to urban particulate pollution.

Keywords: Urban air quality, Aerosols, Africa cities, PASMU project

\section{INTRODUCTION}

Air pollution is a global public health problem and its extent in the cities of many developing countries is still poorly known (Kirenga et al., 2015). Among all pollutants, particulate pollution is highly harmful to health, especially in low- and middle-income countries (Kalisa et al., 2019). Recent studies have shown alarming levels of particulate pollutants in West African cities (Dieme et al., 2012; Djossou et al., 2018), due to various sources of pollution that are generally uncontrolled and relatively close to living areas Val et al. (2013) and Adon (2019) highlighted the inflammatory nature of particles rich in organic carbon $(\mathrm{OC})$ and small in size emitted by urban west African sources. Also, a few studies (Cohen et al., 2005; Liousse et al., 2019) have shown the importance of premature death estimations for cardiovascular, lung cancer and respiratory diseases causes, due to anthropogenic fine particles in West Africa.

Anthropogenic sources are harmful in developing countries because of the absence or 
ineffectiveness of regulations on pollutant emissions. The typical anthropogenic sources in subSaharan Africa are domestic fires (biomass and gas for cooking), road traffic (combustion emissions and dust resuspension), waste combustion, industrial activities (petrochemicals, agriculture, construction. More precisely, air quality in Cote d'Ivoire and in West Africa, is impacted by emissions from a very old vehicle fleet, on average 20 years according to the Ministry of Transports, (2017), using poor quality fuel and from the use of traditional stoves with wood and/or charcoal incomplete consumption. Furthermore, open burning of waste in urban areas of Africa is a very common phenomenon due to the ineffectiveness of municipal waste collection and management policies (Keita et al., 2020). In addition to these local sources, there are important imported sources of aerosols: (1) desert dust and natural savannah fire sources from prevailing Harmattan wind (north wind) as well as (2) marine aerosols brought by monsoon flow (southwest wind).

Unlike developed countries, most cities in the developing countries do not have the capacity to monitor urban air concentrations in order to effectively solve the problem of air pollution. In West Africa, Dakar (in Senegal), is the only city with an air quality monitoring network. Considering the anthropogenic source diversity and their strength which is expected to increase if no regulation is taken (Liousse et al., 2014), it is necessary to expand pollution studies in African cities.

Studies carried out in West Africa have shown high concentrations of $\mathrm{PM}_{2.5}$ and $\mathrm{PM}_{10}$ in several cities: Accra in Ghana (Arku et al., 2008; Dionisio et al., 2010); Dakar in Senegal (Dieme et al., 2012; Val et al., 2013) and Bamako in Mali (Val et al., 2013; Antonel and Chowdhury, 2014). In the European program DACCIWA (Dynamic-Aerosol-Chemistry-Cloud Interactions in West Africa), Djossou et al. (2018) observed average concentrations (February 2015-March 2016) in Abidjan (Cote d'Ivoire) and Cotonou (Benin), well above WHO standards. Similarly, in the POLCA program (POLlution of African Capitals), Doumbia et al. (2012) measured PM 2.5 concentrations at an urban site in Dakar from June 2008 to May 2009, which were above the WHO standard. These various studies highlight overexposure of populations to atmospheric particles whose economic impacts were assessed by Stern and van Dijk (2017), and mortality by Cohen et al. (2005) and in Global Burden of Disease Study 2010 by Murray et al. (2012). Also, within the framework of DACCIWA, Keita et al. (2020) have calculated emission factors (EF) for particulate pollutants based on sources and considering the specificities of African regions in order to improve emission inventories for these pollutants. These results showed very high EF values, highlighting the importance of particulate pollutant emissions from sources such as domestic fires and traffic, which are very important sources of pollution in West Africa. These different results are a challenge for us and we must act.

The lack of air pollution monitoring networks, even in the most urbanized cities, due to the high cost of acquiring and maintaining air quality measurement equipment can be offset by the installation of low- and medium-cost sensors offering simple and inexpensive alternatives. Although accessible, these sensors cannot be deployed always and everywhere. To overcome this problem, an experimental existing methodology based on the use of low-cost sensors during intensive measurement campaigns and a geostatistical treatment tool is used to assess particulate air pollution in two cities of Cote d'Ivoire. Specifically, this study quantifies the level of $\mathrm{PM}_{10}$ and $\mathrm{PM}_{2.5}$ concentrations and their spatial and temporal distribution in these cities of different geography and morphology (Korhogo and Abidjan). This work is carried out within the framework of the project Air Pollution and Health in Urban Areas, Cote d'Ivoire (PASMU).

\section{METHODOLOGY}

\subsection{Description of the Experimental Sites}

In this study, two measurement campaigns were conducted successively in Korhogo (January $3^{\text {rd }}$-January $16^{\text {th }}, 2019$ ) and in Abidjan (January $20^{\text {th }}$-February $10^{\text {th }}, 2019$ ), whose economic activities, transport specificities and types of roads, cooking fuels, population practices and local meteorology differ. As shown in Fig. 1, the population densities of these two cities are also very different, with a population of Abidjan 10 times that of Korhogo. It can also be noticed that population densities from south to center of Cote d'Ivoire are generally higher compared to areas 


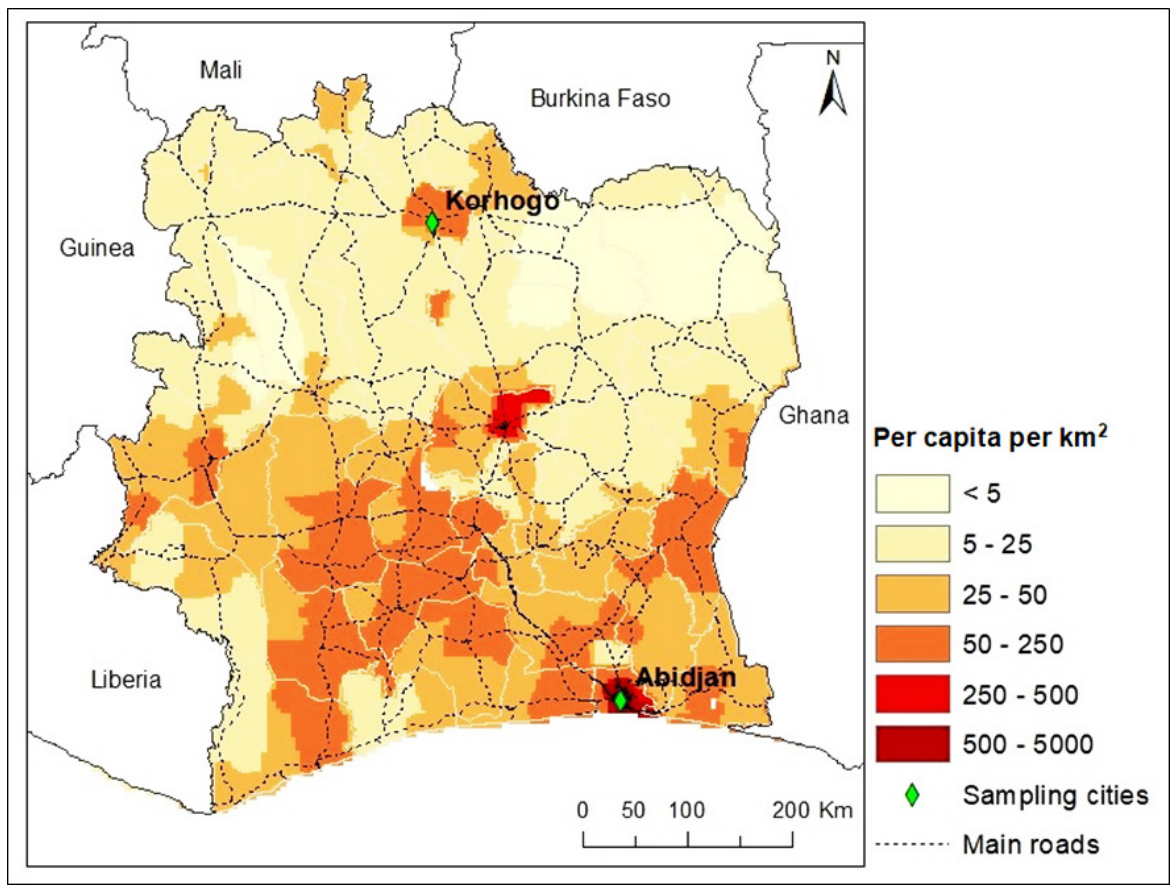

Fig. 1. Map of the population density of Cote d'Ivoire, the position of two application cities in Cote d'Ivoire is shown by green diamond. Green diamond represents each measurement cities. Data from https://www.diva-gis.org/gdata

further north. The population density of Korhogo remains high for a northern region due to agricultural industries. In each city, the measurement sites are chosen to allow representative mapping of the variability of pollution including different districts. Generally, measurement sites can be of 3 types: (1) Local stations, generally used to control classified establishments, are located in proximity of the polluted source to be monitored and therefore under the direct influence of this pollution source; (2) Urban background stations, used to monitor urban pollution, are located in an urban environment but under the indirect influence of pollution sources, and (3) Background stations, are located in a peri-urban environment. It is important to note that local stations are therefore not included in this study as they only provide very local information (Jeannée et al., 2006). In our study, urban background stations are mainly influenced by major west-African urban sources, i.e., the domestic fires, the waste burning and the road traffic (from combustion or non-combustion). In addition, dust resuspension of particulate matter is also important because of road conditions and urban developments. In this study, 14 non-permanent sites in Korhogo and 20 in Abidjan were sampled for 3 days ( 2 working days and 1 weekend day). The 2 cities and their sampling sites are described below.

\subsubsection{Korhogo sampling site}

Korhogo is the third largest city in Cote d'Ivoire in terms of population. A large part of the city's area is not built. Korhogo is a city still marked by agricultural activities with a few rare agricultural product factories for processing and packaging. The principal sources of anthropogenic emissions in Korhogo are traffic sources with intense activities of heavy vehicles, national bus line but also motorcycle traffic, which is a particularity of Korhogo. Furthermore, in this city, only main roads are paved and represent, $10 \%$ of the urban roads (AGEROUTE, 2020). This implies important road resuspension of aerosols which is also a major source of PM emissions. Another important anthropogenic source is the domestic fire with the use of firewood for economic reasons or for convenience as because these resources are still available in the surrounding villages. In addition to the local anthropogenic sources present in Korhogo, the harmattan wind is a major contributor of PM in the dry season with desert dust, biomass burning and aerosol transport. Fig. 2 shows the geographical distribution of the 14 measurement sites as well as the boundaries of the city of Korhogo. Also, the specificities of each sites are summarized in Table S1 (in Supplementary 


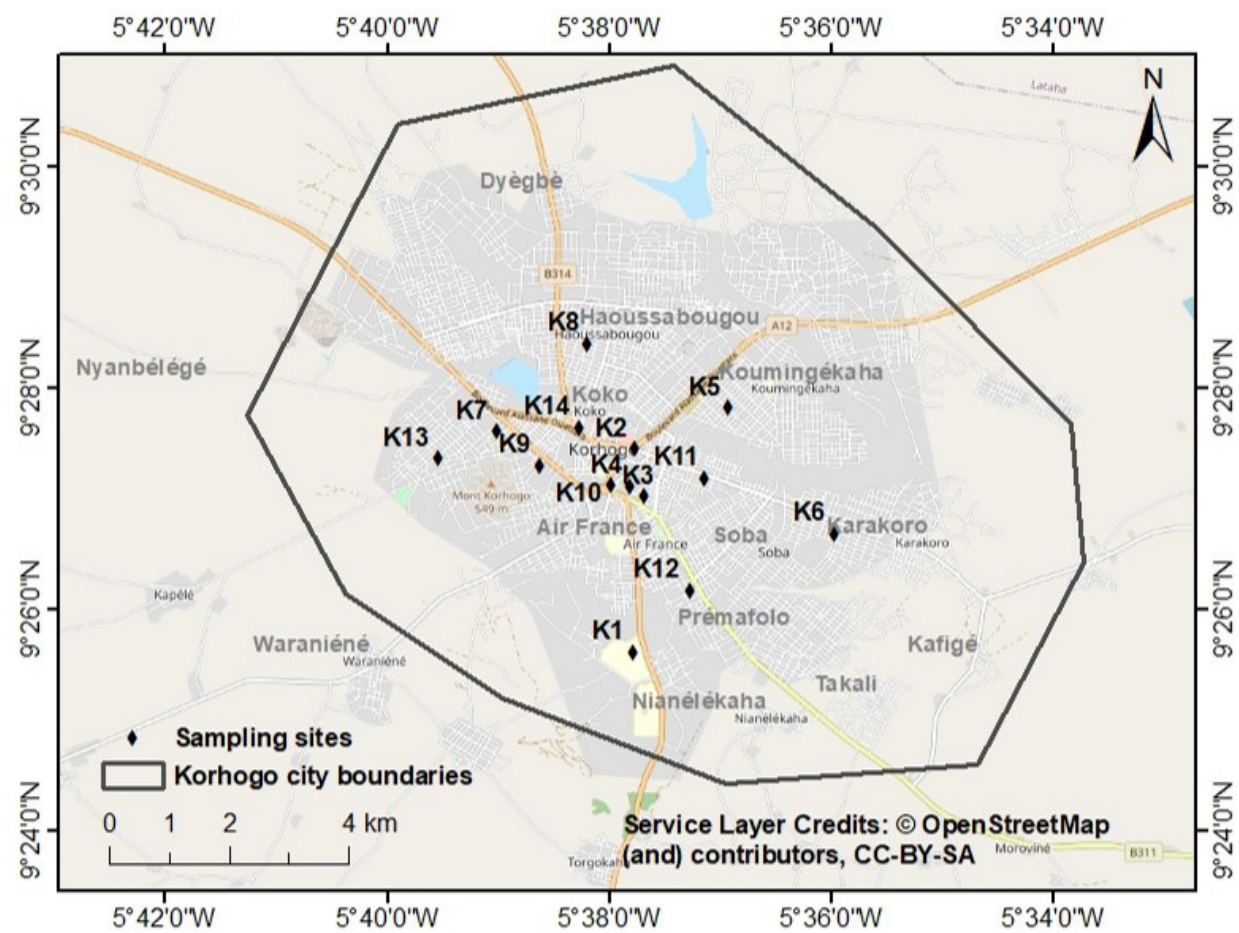

Fig. 2. Localization of measurement sites in Korhogo (Cote d'Ivoire). Green diamond represents each measurement site with its corresponding ID, described in the Tables S1 and S3 and the black lines represent the boundaries of Korhogo city.

files), where are mentioned site localizations as well as roads infrastructure and possible sources of pollution around. Additional information like that geographic positions of Korhogo measurement sites is given in Table S2 (in Supplementary files). Sites $K_{2}, K_{10}, K_{11}$ and $K_{14}$ are surrounded by paved roads (i.e., under the influence of the traffic source) and far from other urban sources. The other sites are located in residential areas where wood is used extensively for cooking, with the exception of $\mathrm{K}_{1}$ site which is in a peri-urban area but close to a major traffic road.

\subsubsection{Abidjan sampling sites}

Abidjan is the economic capital regrouping the main industrial activities with a population of $4,707,404$ inhabitants for an area of $2,119 \mathrm{~km}^{2}$ according to the General Census of Population and Housing (RGPH, 2014).

Abidjan is an Autonomous District with different levels of urbanization and includes populations of different social classes. Its principal anthropic sources are also traffic, domestic fires and waste burning sources with different practices depending on the communes. For instance, wood is intensively used in the commune of Yopougon whereas the use of gas dominates in Cocody. Less road dust particles compared to Korhogo are expected since more than $50 \%$ of roads are paved according to MCLAU, (2015), (MCLAU for Ministère de la Construction, du Logement, de I'Assainissement et de l'Urbanisme). However, this value also depends on the communes. In Cocody, Le Plateau and Marcory, a higher percentage of paved roads are observed compared to Abobo and Yopougon, where a large part of the city population lives.

Fig. 3 shows the geographical distribution of the measurement sites in Abidjan and boundaries of the sampled communes, which represent the study area of this city. In Supplementary files, Table S5 provides information on the 20 sites sampled in Abidjan. In this study, only the subprefecture of Bingerville (Abidjan peripheral municipality) is associated with the 10 municipalities of Abidjan, because Bingerville city is completely integrated into Abidjan. As shown in, in Supplementary files, in Table $\mathrm{S} 5$, measurement sites are located in neighborhoods inhabited by high-income populations $\left(A_{1}, A_{2}, A_{11}, A_{20}, A_{4}, A_{6}, A_{8}, A_{14}, A_{15}\right)$, middle $\left(A_{18}\right)$ and low $\left(A_{3}, A_{5}, A_{7}, A_{9}\right.$, $\left.A_{10}, A_{12}, A_{13}, A_{16}, A_{17}, A_{19}\right)$. The latter sites are generally close to unpaved roads. In addition, Table S6 (in Supplementary files), give latitude and longitude of Abidjan measurement sites. 


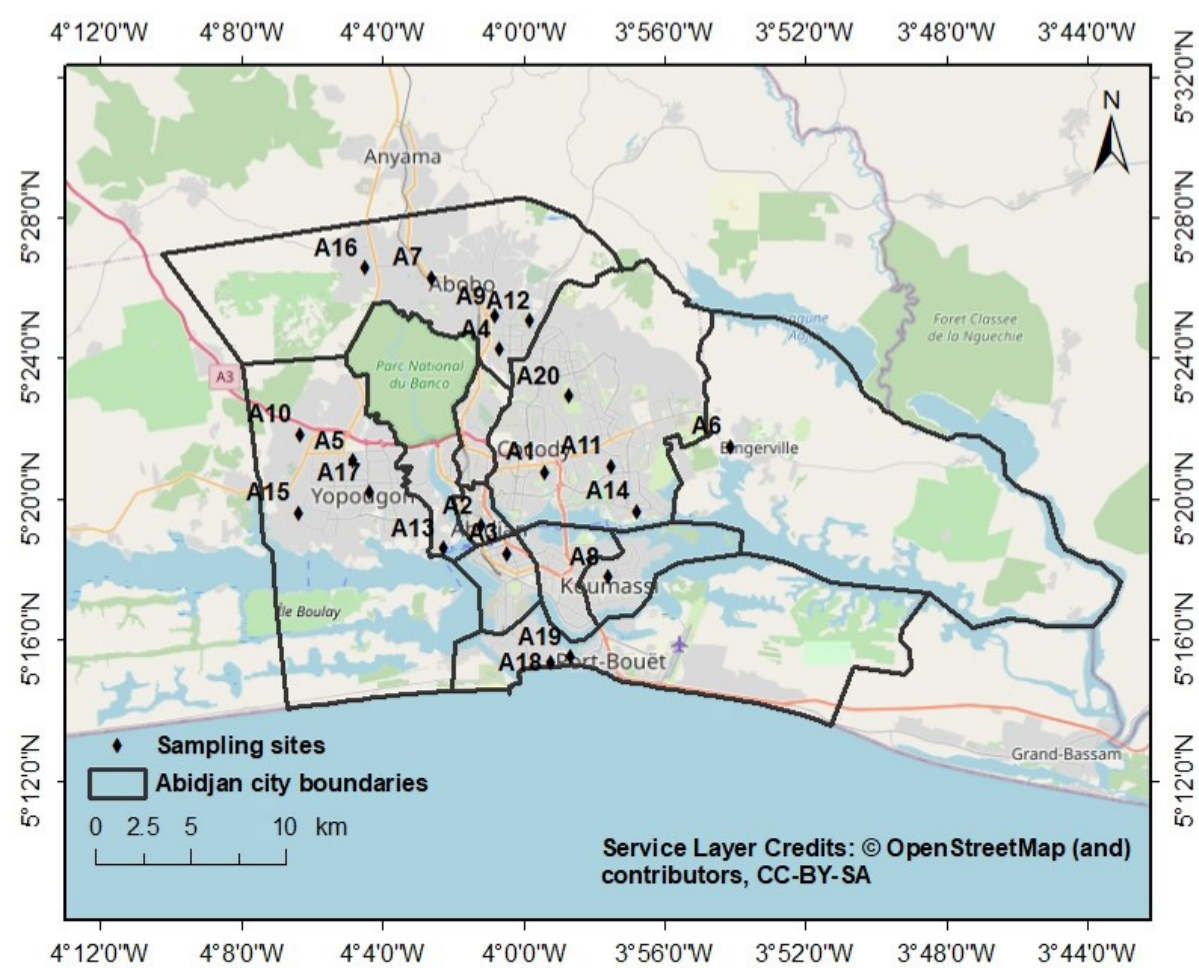

Fig. 3. Localization of measurement sites in Abidjan (Cote d'Ivoire). Green diamond represents each measurement site with its corresponding id site, described in the Tables S2 and S4 and black lines represent the boundaries of communes included in this study.

\subsubsection{Meteorological data and surrounding pollution}

To assess the impacts of weather parameters on PM concentration levels measured at each site during the 3-day sampling period, temperature, wind intensity and direction are analyzed at local and regional scales. These meteorological parameters are obtained from the data of the synoptic stations managed by the Agency for the Safety of Air Navigation in Africa and Madagascar (ASECNA) at Korhogo Airport (station No. 65536) and at Felix Houphouet-Boigny Airport in Abidjan (station No. 65578).

Average daily temperatures (available on https://www.accuweather.com/fr/ci/cote-divoireweather) show a range of 32 to $36^{\circ} \mathrm{C}$ in Korhogo and 31 to $35^{\circ} \mathrm{C}$ in Abidjan. These daily averages do not vary by more than one degree over several consecutive days. This may suggest stability of the atmosphere.

Wind roses presented in Fig. 4 highlight important north (N) and north-east (NE) winds in Korhogo (Fig. 4(a)) and south-west (SW) winds in Abidjan (Fig. 4(b)). The regional climate is defined by the position of the Intertropical Convergence Zone (ITCZ), which regulates the succession of weather seasons (Nouaceur and Murarescu, 2020). During measurement campaign, the ITCZ is located above the latitude of Abidjan, favoring the arrival of air masses from the south to Abidjan and air masses from the north to Korhogo where high temperature and low relative humidity are typical for dry seasonal conditions. Such features are confirmed by the use of HYSPLIT trajectories (https://www.ready.noaa.gov/HYSPLIT_traj.php) as shown by Fig. S1 (in Supplementary files). HYSPLIT trajectories represent the movement of air masses arriving at the study areas during the measurement campaigns. Fig. S1 shows 14- and 21-days back-trajectories before the end dates of each measurement campaign respectively for Korhogo and Abidjan respectively. It gives an overview of the dominant air mass origins over the measurement period. As expected, Korhogo is under the influence of northern trajectories whereas Abidjan is under the influence of southern air masses, associated to air masses coming from the Nigerian coast.

In order to identify which aerosols could be advected into Korhogo and Abidjan using these trajectories, emphasis was put on MODIS active fire maps and Aerosol Optical Thickness data (AOD), obtained from https://neo.sci.gsfc.nasa.gov. Fig. S2 present actives fires (a and b) and 


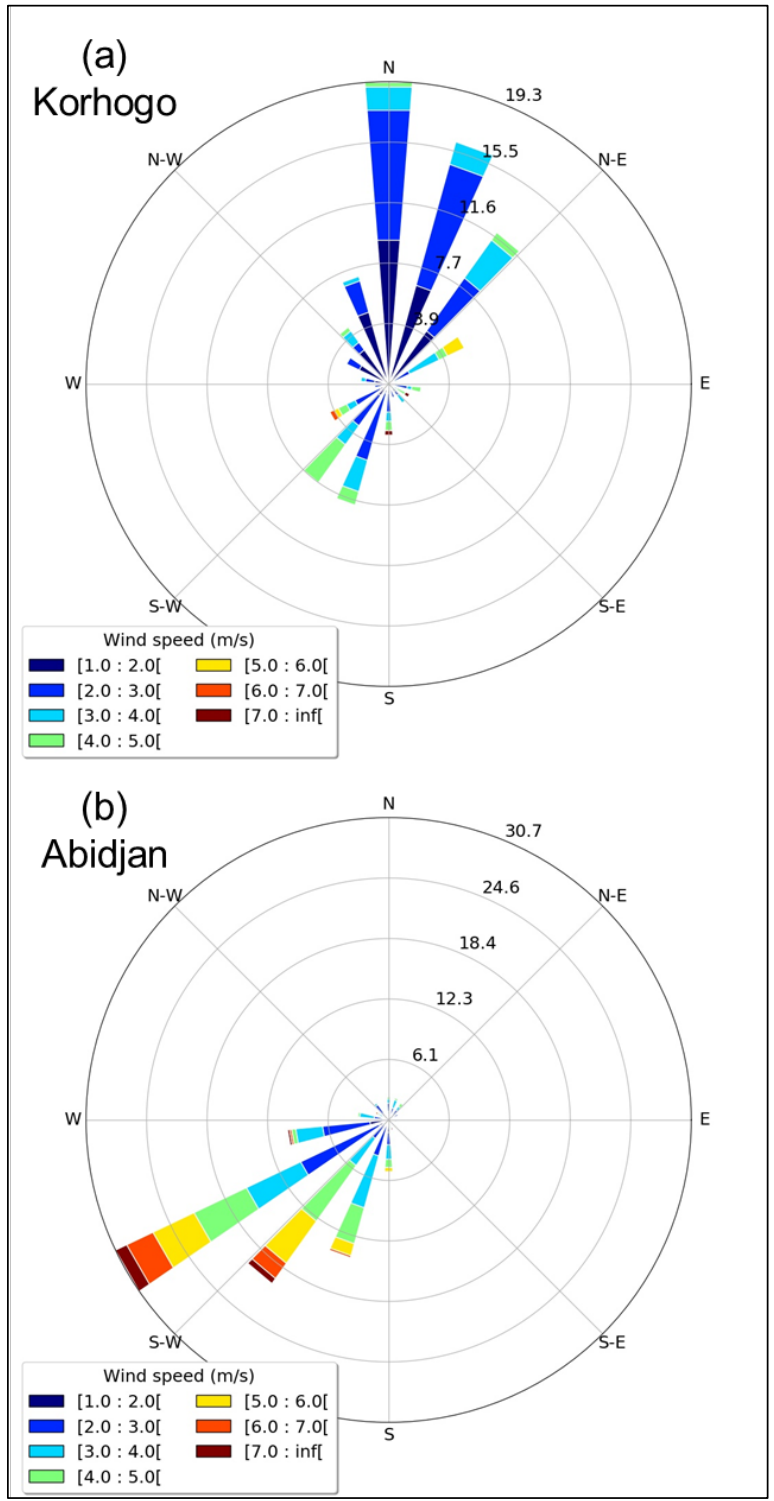

Fig. 4. Wind rose from synoptic station measurements during the study periods in Korhogo (a) and Abidjan (b) in Cote d'Ivoire.

Aerosol Optical Depth (c and d) in January ( $a$ and c) and February (b and d) 2019, representative of the study period. Associated with Fig. S1, this shows that Korhogo is under the influence of regional winds that carry desert dust and biomass burning aerosols coming from the north and south of the city. While at Abidjan these regional winds show that only marine aerosols are expected.

\subsection{Material and Methods}

\subsubsection{Measurement campaigns and equipment}

The first step of the methodology deals with intensive data collection through measurement campaigns conducted at sites in the two cities, as presented in previously. The measurement campaigns of $\mathrm{PM}_{10}$ and $\mathrm{PM}_{2.5}$ concentrations were carried out with 4 portables $\mathrm{PM}$ measuring devices (Aeroqual monitor $\mathrm{S} 500$ with $\mathrm{PM}_{10} / \mathrm{PM}_{2.5}$ sensor). Particulate pollution is measured over 3 days at each site, with 2 consecutive working days and 1 weekend day, because these 2 periods (working and weekends days) present different activities levels in urban areas. Indeed, studies have shown different levels of pollution at these 2 periods of the week (Doumbia et al., 2012; Adame et al., 2014; Adon et al., 2020). During the campaigns, the measurements are not 
simultaneous on all sites of each city because rotations are organized. During the campaigns, the measurements are not simultaneous on all sites of each city. Rotations are organized with at maximum 4 sites running in parallel. This is possible due to atmospheric stability detailed in the meteorological paragraph. This technique of measuring on non-permanent sites during short periods allows to maximize measurements on a large number of non-permanent sites with a small number of equipment.

In this study, optical $\mathrm{PM}_{10} / \mathrm{PM}_{2.5}$ sensor on $\mathrm{S} 500$ Aeroqual monitor is used to measure particulate pollution, because it is easy to use and take up very little space. This sensor covers a concentration range from 0 to $1000 \mu \mathrm{g} \mathrm{m}^{-3}$, and simultaneously measures $\mathrm{PM}_{10}$ and $\mathrm{PM}_{2.5}$. These types of sensors are based on light scattering and have an accuracy that can be influenced by the physical and chemical characteristics of aerosols (Wang et al., 2015). The measuring device has been placed in a box to protect it from natural elements. The device is installed at a height of between 2 and $3 \mathrm{~m}$. The time step chosen is 3 minutes, in order to allow fine sampling and to store the data over the entire measurement period. After data retrieval, the data logger of the equipment is formatted before being installed at another site.

Quality Control data: The evaluation of the uncertainties associated with low- and middle-cost sensor measurements is the subject of several studies, as shown by Wang et al. (2015) who tested 3 low-cost sensors in combustion chambers with different results. Consequently, it is necessary to evaluate and correct optical sensor concentration measurements against a reference method (Clements et al., 2017). The reference method here proposed, is the gravimetric method. At some of the selected sites, aerosol sampling lines are installed, including a fixed flow pump, a volume meter, a valve, an aerosol size selection system (cane or cut-off head). These lines allow sampling by filtration of aerosols on quartz filters, over the same periods the same sites than the low-cost sensor measurements. The filters are weighed on a submicron balance before and after exposure in order to deduce the collected aerosol masses. This reference method has been used and validated in several research projects and programs such as the International Network to study Deposition and Atmospheric chemistry in Africa (INDAAF) program (ref.) and the DACCIWA program (Djossou, 2018).

Geometrical means of the measurements obtained with low-cost sensors are compared with those obtained by the gravimetric method (reference method). Geometrical means concentrations of optical sensors are consistently lower than the gravimetric concentrations of $2.7 \pm 1.1$ and 3.5 \pm 0.9 for $\mathrm{PM}_{10}$ and $\mathrm{PM}_{2.5}$ respectively. The standard deviation of these coefficients is higher for $\mathrm{PM}_{10}$ than for $\mathrm{PM}_{2.5}$, the latter having more points of comparison. It is worth noting that these values agree with those of Zuidema et al. (2019) who showed the need for a correction factor of 2.9 for an optical photometric sensor (GP2Y1010AUOF, Sharp Electronics, Osaka, Japan) compared to the gravimetric method. Similarly, Egondi et al. (2016) also showed overestimated concentration values given by the DustTrak II 8532 portable samplers compared to a reference method. These factors (2.7 and 3.5) are then applied to $\mathrm{PM}_{10}$ and $\mathrm{PM}_{2.5}$ concentrations at all measurement sites.

\subsubsection{Spatial mapping}

Geographic Information System (GIS) provide a robust method of spatial analysis through interpolation. The most commonly used methods, kriging (geostatistical method) and reverse weighting of IDW (deterministic method), have already been compared in works. For example, Shukla et al. (2020) in the Delhi megacity showed that kriging and IDW methods are associated to errors close to $22 \%$ and $24 \%$ respectively. In addition, Bahino et al. (2018) carried out a spatial distribution of gaseous pollutants $\left(\mathrm{NO}_{2}, \mathrm{SO}_{2}, \mathrm{NH}_{3}, \mathrm{HNO}_{3}\right.$ and $\left.\mathrm{O}_{3}\right)$ in Abidjan (Cote d'Ivoire) and Cotonou (Benin) during the dry season within DACCIWA Program. The latter study included also a comparison between kriging and IDW, and showed that IDW method is associated to lower uncertainty than kriging method. In addition, our measurement network (number of points and geographic locations) is developed on the basis of the network of Bahino et al. (2018); therefore, in this study, the IDW method is chosen and applied to the collected data.

ArcGIS version 10.3 software (ESRI Inc.) is used because it combines geostatistical data processing and map edition. The shapefiles for map editing are available for free on OpenStreetMap (https://www.openstreetmap.org). Briefly, IDW interpolation allows to predict the concentrations around a sampled point from the following formula presented in Eq. (1). 
$Z_{p_{j}}=\sum_{i=1}^{N} \lambda_{i} \times Z_{O_{i}}$

where,

$Z_{o_{i}}$ is the observed value at location $i$; form geometrical mean of measured values at each site during the different measurement campaigns. These geometrical means, averages deviation, minimums and maximum are available, for Korhogo in Table S3 (for PM 10 ) and Table S4 (for PM 2.5 ) and for Abidjan in Table S7 (for $\mathrm{PM}_{10}$ ) and Table S8 (for $\mathrm{PM}_{2.5}$ ), in Supplementary files for each site.

$Z_{p_{j}}$ is the predicted value for location $j$;

$N$ is the number of measured sample points surrounding the predicted location that will be used in the prediction;

$\lambda_{i}$ are weighting factors applied at each measured value at location Oi. They decrease according to the separation distance.

The geostatistical analysis of the data enables the values to be evaluated in order to develop the spatial variation maps. Thus, the IDW method calculates values from the collected data for each point (unsampled and sampled) and gives average predicted values everywhere (Zamri et al., 2012; Rivera-González et al., 2015; Bahino et al., 2018).

The Root Mean Square Error (RMSE) (McKeen et al., 2005; Savage et al., 2013; Chai and Draxler, 2014) and the Mean Absolute Error (MAE) (Chatterjee et al., 2013; Jerez et al., 2013; Taylor et al., 2013) are the two parameters widely used to evaluate the quality of the predictions of interpolation methods. In order to assess the quality of the prediction in the two cities, both RMSE and MAE values are calculated for each measurement campaign following the formulas present in Eqs. (2) and (3).

$R M S E=\sqrt{\frac{1}{N} \sum_{i=1}^{N}\left(Z_{P_{i}}-Z_{O_{l}}\right)^{2}}$

$M A E=\frac{1}{N} \sum_{i=1}^{N}\left|Z_{P_{i}}-Z_{O_{l}}\right|$

where,

$Z_{P_{i}}$ and $Z_{O_{i}}$ are respectively the predicted and observed value for a location $i$;

$N$ is the number of measured sample point.

Table 1 presents such values for the 2 cities as well as the coefficient of variation of error. In Abidjan, the MAE values are lower than the RMSE values due to the high uncertainties associated with some sites whereas no marked differences appear in Korhogo. Also, both coefficients are higher in Korhogo than in Abidjan: that could be due to the high concentration values found in Korhogo. As shown in Table 1, the coefficients of variation of error in Abidjan are higher than in Korhogo. These low values obtained in Korhogo may be due to a smaller study area than in Abidjan. This analysis highlights the impact of the distance between measurement sites on the uncertainties.

\section{RESULTS AND DISCUSSIONS}

\subsection{Spatial Distribution of PM Concentrations}

\subsubsection{Korhogo PM concentrations maps}

As previously described, the $\mathrm{PM}_{10}$ and $\mathrm{PM}_{2.5}$ concentrations obtained by geographical averages allowed the mapping of spatial variations for the Korhogo study area. These maps are presented in Figs. 5(a) and 5(b), respectively for the $\mathrm{PM}_{10}$ and $\mathrm{PM}_{2.5}$. Concentrations are very high, between $212.2 \mu \mathrm{g} \mathrm{m}^{-3}$ and $534.7 \mu \mathrm{g} \mathrm{m}^{-3}$ for $\mathrm{PM}_{10}$ and $54.3 \mu \mathrm{g} \mathrm{m}^{-3}$ and $218 \mu \mathrm{g} \mathrm{m}^{-3}$ for $\mathrm{PM}_{2.5}$ and well above the World Health Organization (WHO) standards which stipulate that $\mathrm{PM}_{2.5}$ should not exceed $25 \mathrm{\mu g} \mathrm{m}^{-3}$ 24-hours mean and that $\mathrm{PM}_{10}$ not exceed $50 \mu \mathrm{g} \mathrm{m}^{-3} 24$-hours mean. 
Table 1. Interpolation error statistics, where RMSE is root mean absolute error in $\mu \mathrm{g} \mathrm{m}^{-3}$; MAE is mean average error in $\mu \mathrm{g} \mathrm{m}^{-3}$ and $\mathrm{CV}$ is mean of coefficient of variation of error in \%.

\begin{tabular}{lllll}
\hline \multirow{2}{*}{ Pollutants } & \multicolumn{2}{c}{ Korhogo } & & \multicolumn{2}{c}{ Abidjan } \\
\cline { 2 - 3 } \cline { 5 - 6 } & $\mathrm{PM}_{10}$ & $\mathrm{PM}_{2.5}$ & & $\mathrm{PM}_{2.5}$ \\
\hline Root Mean Absolute Error (RMSE) & 97.0 & 43.2 & 41.5 & 24.9 \\
Mean Average Error (MAE) & 105.6 & 40.0 & 31.0 & 19.98 \\
\% Coefficient of Variation of error & $33.4 \pm 12.6$ & $36.7 \pm 31.7$ & $42.5 \pm 41.8$ & $39.7 \pm 29.2$ \\
\hline
\end{tabular}
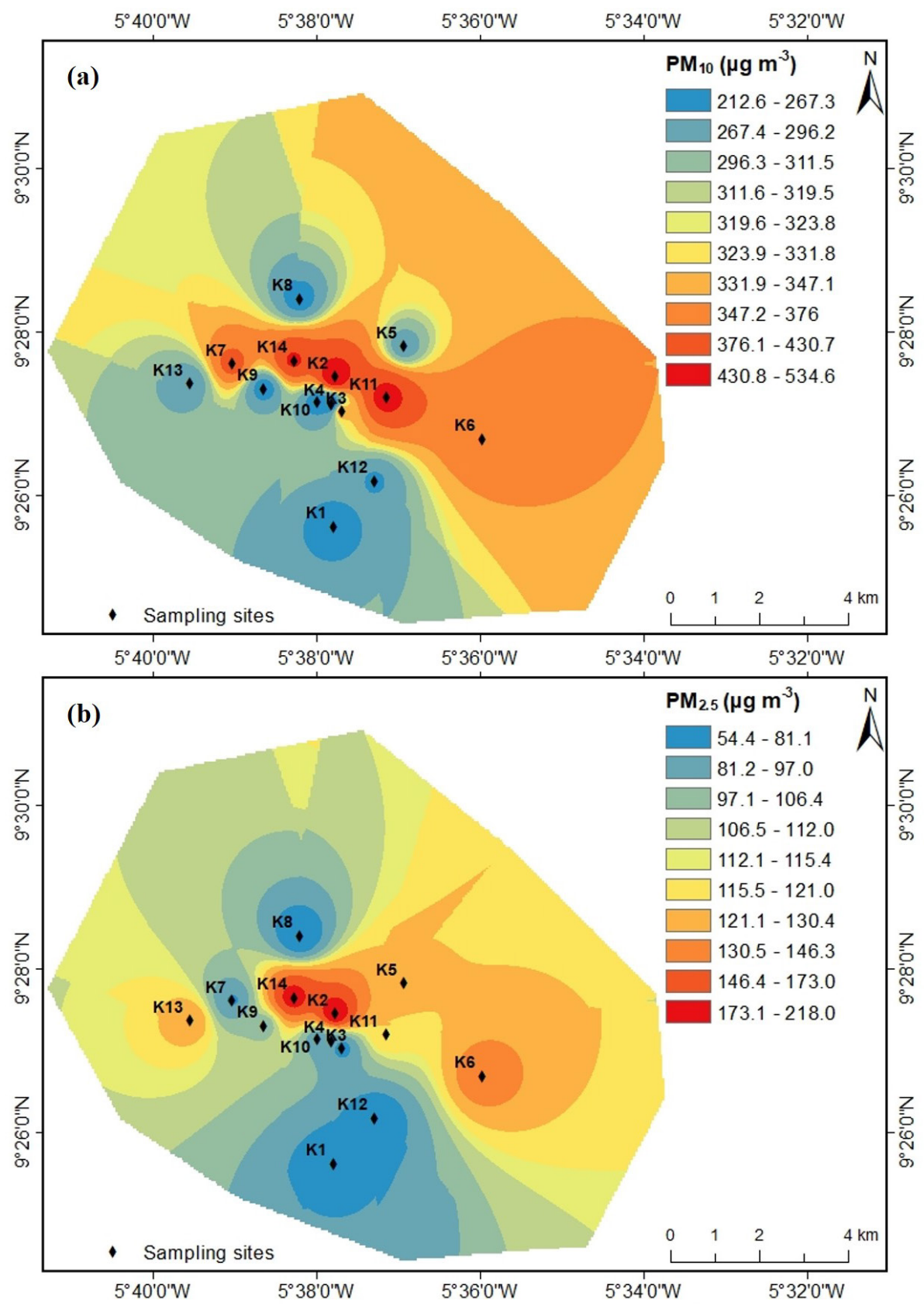

Fig. 5. Spatial variation of $\mathrm{PM}_{10}$ (a) and $\mathrm{PM}_{2.5}$ (b) concentrations in Abidjan (Cote d'Ivoire), where black diamonds represent each measurement site.

As shown in Fig. 5(a), the measurement sites in the city downtown have higher $\mathrm{PM}_{10}$ concentrations, namely $\mathrm{K}_{2}$ with $534.7 \mu \mathrm{g} \mathrm{m}^{-3}, \mathrm{~K}_{6}$ with $374.4 \mu \mathrm{g} \mathrm{m}^{-3}, \mathrm{~K}_{11}$ with $475.1 \mu \mathrm{g} \mathrm{m}^{-3}$ and $\mathrm{K}_{14}$ with $446.7 \mu \mathrm{g} \mathrm{m}^{-3}$ compared to the sites in the northern and southern outskirts of the city such 
as $\mathrm{K}_{1}$ with $241.4 \mu \mathrm{g} \mathrm{m}^{-3}$, $\mathrm{K}_{8}$ with $245.1 \mu \mathrm{g} \mathrm{m}^{-3}$ and $\mathrm{K}_{12}$ with $261.2 \mu \mathrm{g} \mathrm{m}^{-3}$. This can be explained by the economic activities mainly occurring in Korhogo downtown, associated with intense road traffic dominated by 2 -wheel vehicles and the presence of the urban bus stations. The highest concentrations observed in $\mathrm{K}_{2}, \mathrm{~K}_{11}$ and $\mathrm{K}_{14}$ sites are also due to the proximity of busy highways.

$\mathrm{K}_{13}$ and $\mathrm{K}_{5}$ sites have also high $\mathrm{PM}_{10}$ concentrations because they are in neighborhoods with unpaved roads. Moreover, even if downtown roads are mostly paved, a high resuspension of dust by intense traffic is also observed. Indeed, as mentioned earlier, dust deposition on roads are also observed at Korhogo due to northerly air masses transporting desert dust aerosols at the period of this study (Fig. S1). Such aerosols significantly contribute to the pollution level of Korhogo.

Finally, Fig. 5(a) shows that in Korhogo, $\mathrm{PM}_{2.5}$ and $\mathrm{PM}_{10}$ spatial variation maps roughly present the same pattern of high and low concentrations despite some differences which are detailed in the following section.

\subsubsection{Abidjan PM concentrations maps}

The spatial variation maps of $\mathrm{PM}_{10}$ and $\mathrm{PM}_{2.5}$ concentrations (obtained from the geographical averages of the measured concentration time series) in Abidjan study area are given respectively in Figs. 6(a) and 6(b). The average concentrations are between $38.1 \mu \mathrm{g} \mathrm{m}^{-3}$ and $160.4 \mu \mathrm{g} \mathrm{m}^{-3}$ for $\mathrm{PM}_{10}$ and $23.8 \mu \mathrm{g} \mathrm{m}^{-3}$ and $113.4 \mu \mathrm{g} \mathrm{m}^{-3}$ for $\mathrm{PM}_{2.5}$. For $\mathrm{PM}_{10}$, the highest concentrations are found at sites $A_{7}\left(160.4 \mu \mathrm{g} \mathrm{m}^{-3}\right), A_{18}\left(125.3 \mu \mathrm{g} \mathrm{m}^{-3}\right)$ and $A_{20}\left(120.7 \mu \mathrm{g} \mathrm{m}^{-3}\right)$. The $A_{7}$ and $A_{20}$ sites are located nearby unpaved roads (Table $\mathrm{S} 2$ ) therefore, dust from road resuspension contribute to the increase of concentrations. In $\mathrm{A}_{18}$ site, the high concentrations may be explained by the proximity of important road traffic and industrial activities. In addition, $A_{18}$ and $A_{19}$ sites are located on the sea front, and are therefore subject to a high contribution of marine aerosols.

Sites included in areas with better quality infrastructures and with middle- or high-class populations, have generally lower $\mathrm{PM}_{10}$ concentrations (e.g., $\mathrm{A}_{2}, \mathrm{~A}_{11}$ ) compared to sites in neighborhoods with poor quality infrastructures (e.g., $A_{3}, A_{5}, A_{7}, A_{8}, A_{16}, A_{18}$ and $A_{20}$ ).

Compared to $\mathrm{PM}_{10}, \mathrm{PM}_{2.5}$ spatial variation (Fig. 6(b)) presents high concentrations over most of the study area, despite some very localized low concentrations in $A_{1}\left(32.9 \mu \mathrm{g} \mathrm{m}^{-3}\right), A_{2}\left(24.9 \mu \mathrm{g} \mathrm{m}^{-3}\right)$, $\mathrm{A}_{5}\left(30.8 \mu \mathrm{g} \mathrm{m}^{-3}\right), \mathrm{A}_{14}\left(23.8 \mu \mathrm{g} \mathrm{m}^{-3}\right)$ and $\mathrm{A}_{19}\left(24.5 \mu \mathrm{g} \mathrm{m}^{-3}\right)$. $\mathrm{PM}_{2.5}$ concentrations in northern Abidjan are higher than in southern Abidjan. Indeed, the wind rose of Abidjan shows a dominance of south, southwest winds, which could lead to a transport and an accumulation of pollutants in the northern area of the city, as for Bahino et al. (2018). Values for these sites (A $A_{7}$ with $113.4 \mu \mathrm{g} \mathrm{m}^{-3}$, A9 with $91.7 \mu \mathrm{g} \mathrm{m}^{-3}, \mathrm{~A}_{12}$ with $73.2 \mu \mathrm{g} \mathrm{m}^{-3}$ and $\mathrm{A}_{20}$ with $91 \mu \mathrm{g} \mathrm{m}^{-3}$ ) are 2 to 6 times higher than the WHO daily standard $\left(25 \mu \mathrm{g} \mathrm{m}^{-3}\right)$. Moreover, these sites mainly appear in low income neighborhood. Indeed, in such areas, high concentrations result from the combination of the use of wood for cooking, the proximity of public transport (small bus: gbaka, municipal taxis: wôrô-wôrô) with very old and poorly maintained vehicles and the burning of solid domestic waste due to collection failure. In contrary, the less densely populated areas (high-class districts) have lower concentrations ( sites $A_{1}, A_{2}, A_{14}$ ) than the medium and low-class districts. In these areas (sites $A_{1}, A_{2}, A_{14}$ ), people have higher incomes and are more likely to use gas for cooking than wood and charcoal for cooking activities. Lower concentrations are observed in $A_{5}$ and $A_{19}$ sites, although located in popular districts. That may be due to less intensive combustion activities than usually observed in these districts for the $A_{5}$ site and to the proximity of the sea front for $A_{19}$ site.

\subsection{Relative Importance of Fine Particles}

In order to highlight the relative contribution of particulate size and aerosol sources, spatial variation maps of the percentage of relative contribution of $P M_{2.5}$ to $\mathrm{PM}_{10}$ are presented in Figs. 7 and 8 for Korhogo and Abidjan respectively. Low values represent a high contribution of $\mathrm{PM}_{2.5}$ to $\mathrm{PM}_{10}$, while high percentages represent a low contribution of $\mathrm{PM}_{2.5}$ to $\mathrm{PM}_{10}$. It is important to note that these figures show totally different values for the two cities. In Korhogo, more than $50 \%$ of $\mathrm{PM}_{10}$ are coarse particles, with the highest values in the north and south of the city and the lowest values in the city center, where most urban activities take place. In Abidjan, the situation is totally different: coarse particles in $\mathrm{PM}_{10}$ represent less than $40 \%$, with the highest values in $A_{4}, A_{5}, A_{14}, A_{18}$ and $A_{19}$ sites and the lowest values in $A_{6}, A_{9}, A_{11}, A_{12}, A_{13}$ and $A_{15}$. 

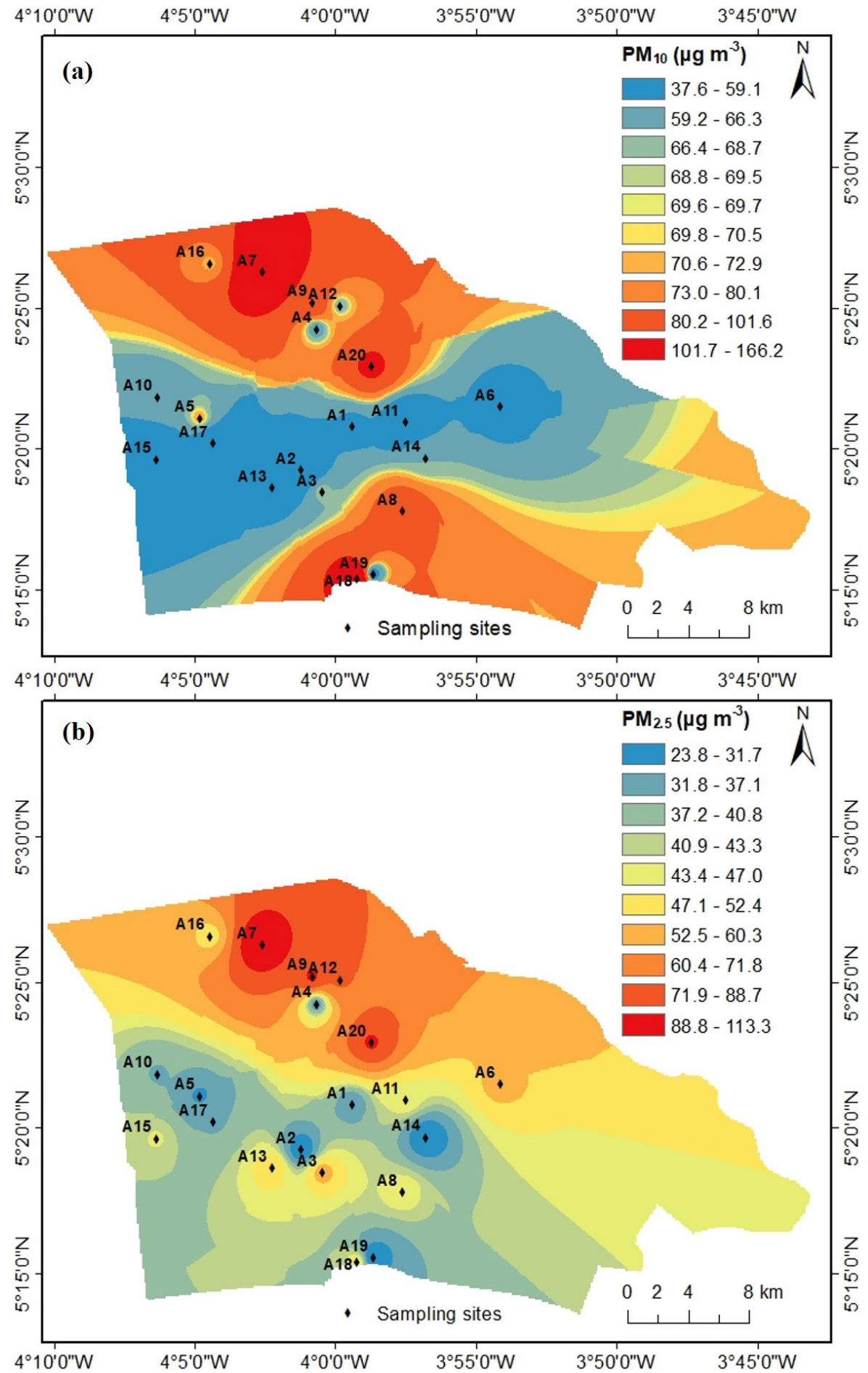

Fig. 6. Spatial variation of $\mathrm{PM}_{10}$ (a) and $\mathrm{PM}_{2.5}$ (b) concentrations in Abidjan (Cote d'Ivoire), where black diamonds represent each measurement site.

In both cities, the lowest values associated with high $\mathrm{PM}_{2.5}$ are found particularly in densely populated sites or in economically very active neighborhoods with intense combustion sources and fine particle emissions. In addition, the percentages of coarse particles $\left(\mathrm{PM}_{2.5-10}\right)$ relative to $\mathrm{PM}_{10}$ are high near unpaved roads and sometimes in areas with heavy traffic.

In Abidjan, low contributions of $\mathrm{PM}_{2.5}$ to $\mathrm{PM}_{10}$ are also observed in industrial areas (site $\mathrm{A}_{18}$ ). In these areas, heavy truck traffic damages the roads and causes dust resuspension. In addition, a contribution from marine aerosols is possible due to the south-westerly (SW) wind direction. 


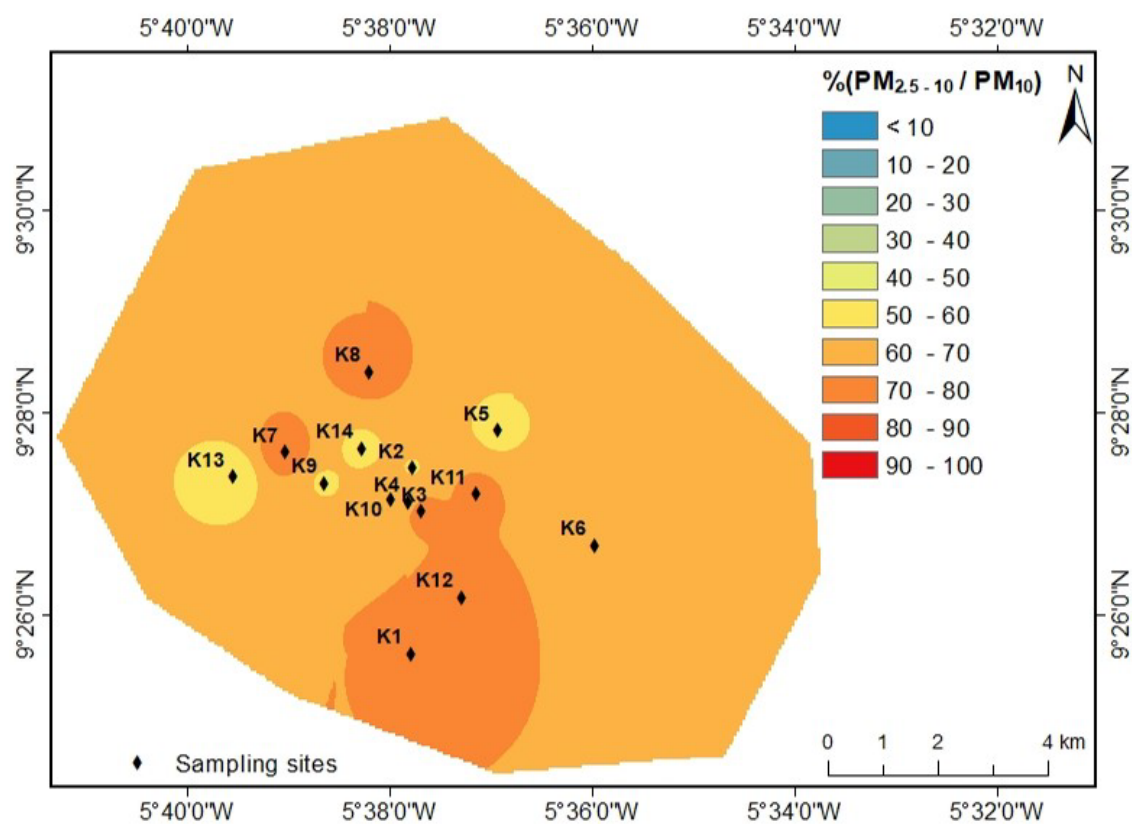

Fig. 7. Spatial variation of relative difference between $\mathrm{PM}_{10}$ and $\mathrm{PM}_{2.5}$ in percentage in Korhogo (Cote d'Ivoire), where black diamonds represent each measurement site.

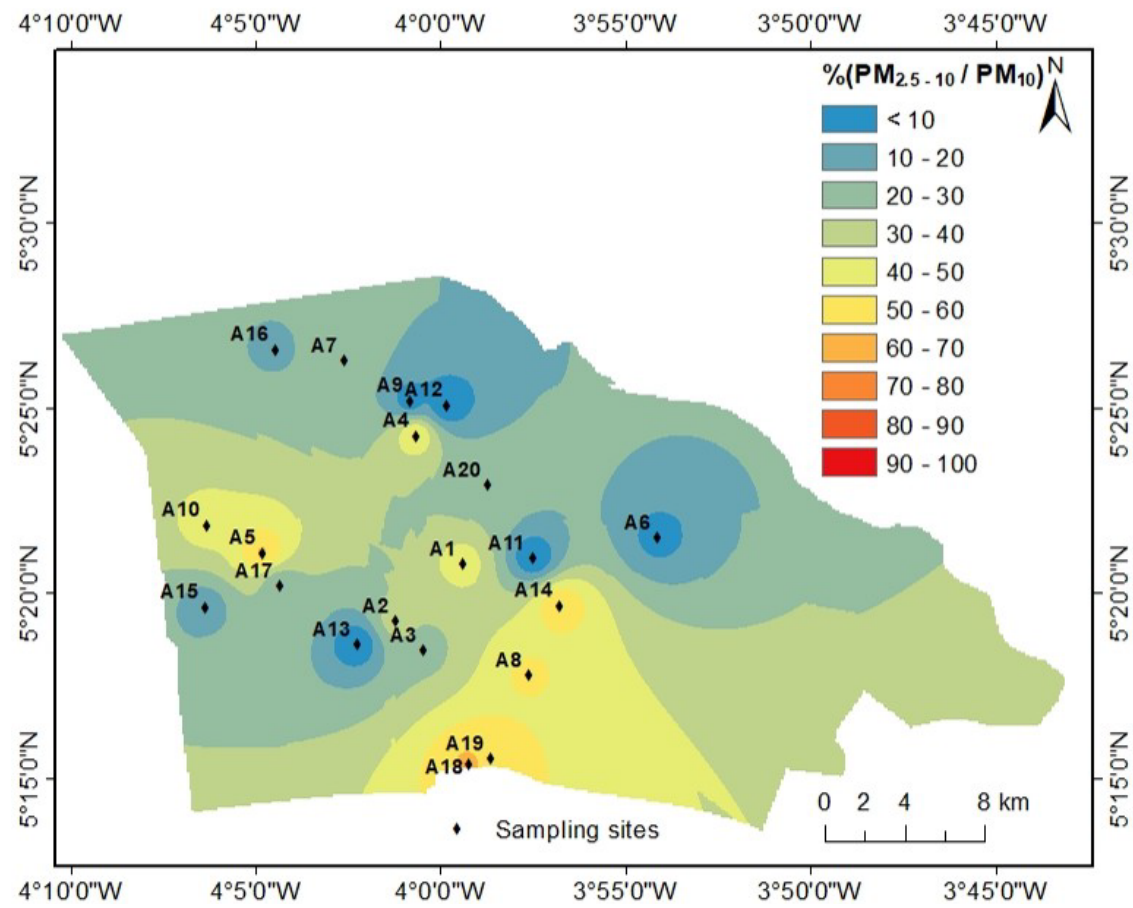

Fig. 8. Spatial variation of relative difference between $\mathrm{PM}_{10}$ and $\mathrm{PM}_{2.5}$ in percentage in Abidjan (Cote d'Ivoire), where black diamond represents each measurement site.

These values are in line with our expectations and confirm the good representation of the measurement sites and the good performance of the spatial distribution, because they reflect the main sources of pollution that influence each city.

\subsection{Daily Distribution of PM Concentrations}

Daily profiles of fifteen minutes average concentrations of PM are shown in Fig. 9. The average daily profiles of $\mathrm{PM}_{10}$ and $\mathrm{PM}_{2.5}$ concentrations in Korhogo are presented in Figs. 9(a) and 9(b) 


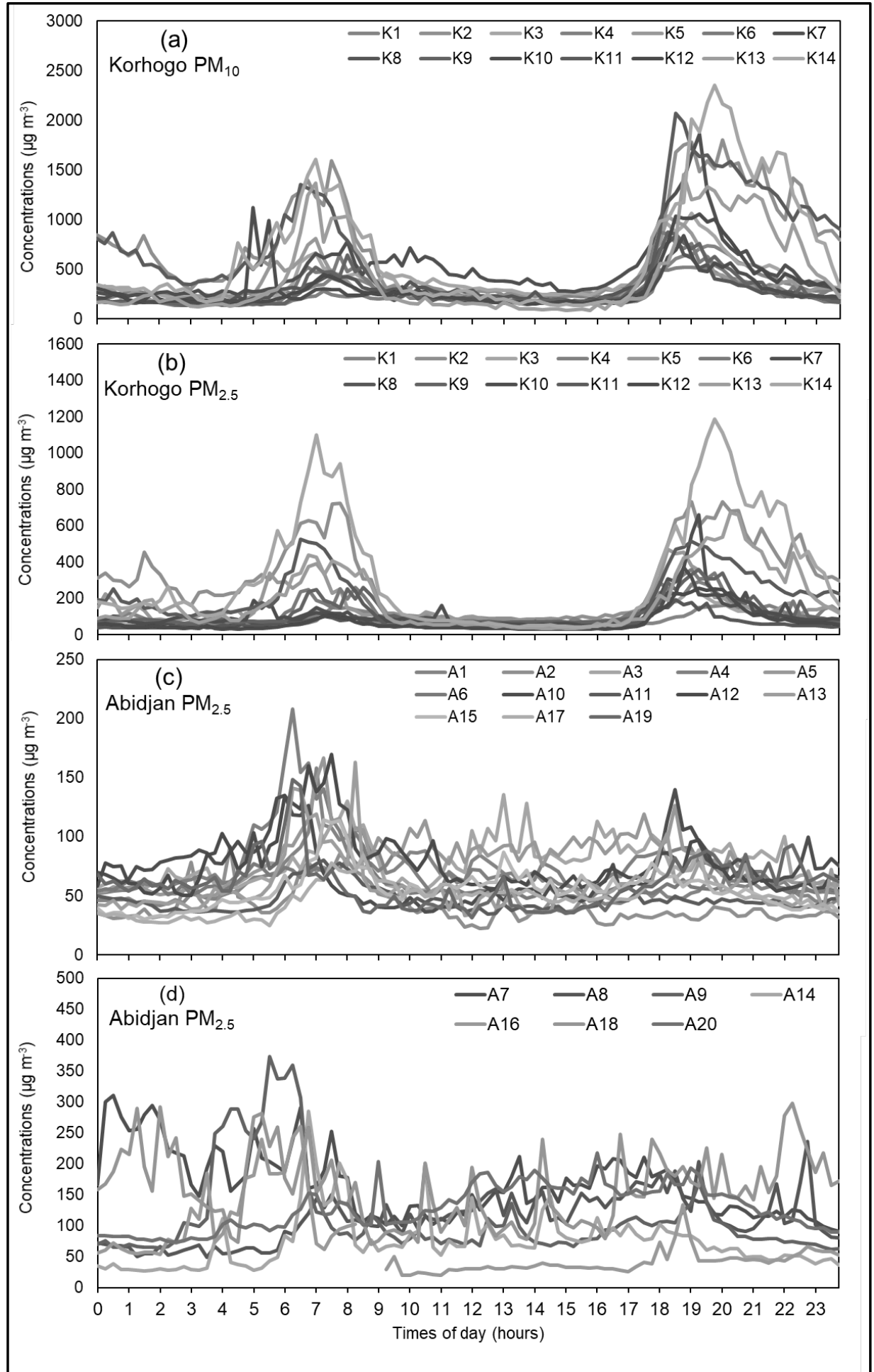

Fig. 9. Daily averages of $P M_{10}$ and $P M_{2.5}$ concentrations in Korhogo $(a, b)$ and $P M_{2.5}$ concentrations in Abidjan (c, d).

respectively. For Abidjan, Figs. 9(c) and 9(d) represent the sites with similar patterns of $\mathrm{PM}_{2.5}$ concentrations and the other sites respectively. Since $\mathrm{PM}_{10}$ and $\mathrm{PM}_{2.5}$ daily profiles are similar in Abidjan, only $\mathrm{PM}_{2.5}$ concentrations are presented here. Note that the daily profiles of $\mathrm{PM}_{10}$ concentrations in Abidjan are shown in Figs. S5(a) and S5(b).

In Korhogo, all the sites show the same daily average concentration profiles for $\mathrm{PM}_{10}$ and $\mathrm{PM}_{2.5}$ respectively in Figs. 9(a) and 9(b), with two very important daily peaks. One peak in the morning 
and one in the evening. These peaks are due to the mix of several local sources: mainly, household sweepings (twice a day), use of firewood (morning and evening), and road traffic (dominated by 2-wheelers). Focusing on these peaks, $\mathrm{PM}_{2.5}$ morning and evening peaks are of similar importance whereas $\mathrm{PM}_{10}$ peak is higher in the evening than in the morning. This could be due to favorable conditions for dust resuspension due to the higher dryness of the soil in the evening caused by sunshine during the day. According to Cheng and Li (2010) and Gualtieri et al. (2015), meteorological parameters such as temperature and relative humidity influence particulate matter concentrations. Moreover, the low values observed during the day, twenty times lower than in morning could be due to a decrease of urban activities. However, it is interesting to note that such low average concentrations observed in Korhogo are still higher than the WHO daily standard.

In Abidjan, Fig. 9(c) shows morning peaks of concentrations which are more important than those of the evening. Traffic source are mainly responsible of these peaks. The difference between the morning and evening peaks can be explained by the fact that the flow of road traffic in the evening is more spread out in time compared to that of the morning. In Fig. 9(d), some sites show no clear daily variation. For example, $A_{18}$ and $A_{20}$ sites show high concentrations throughout the day, characteristic of local economic activities. Indeed, the $A_{8}, A_{18}$ and $A_{20}$ sites are respectively located in a low-income neighborhood (mainly using wood and charcoal for cooking), in a neighborhood under construction and in an industrial area respectively. The daily minimum average concentrations are $19.3 \mu \mathrm{g} \mathrm{m}^{-3}$ for $\mathrm{PM}_{10}$ and $14 \mu \mathrm{g} \mathrm{m}^{-3}$ for $\mathrm{PM}_{2.5}$. These low values are compensated by the high values observed during peaks (beyond $350 \mu \mathrm{g} \mathrm{m}^{-3}$ as well as $\mathrm{PM}_{10}$ and $\mathrm{PM}_{2.5}$ ), thus providing a daily average concentration well above WHO standards. To conclude, this data collection methodology provides daily profiles of PM concentrations, which are important in the analysis of population exposure levels.

\subsection{Comparison with Other Sub-Saharan Africa cities}

Concentrations of $\mathrm{PM}_{10}$ and $\mathrm{PM}_{2.5}$ in Korhogo and Abidjan are generally above the WHO daily exposure standard. As shown previously the local variability of these concentrations is strongly related to the predominant local sources.

Concentrations vary on average from $212.2 \mu \mathrm{g} \mathrm{m}^{-3}$ to $534.7 \mu \mathrm{g} \mathrm{m}^{-3}$ for $\mathrm{PM}_{10}$ and from $57.4 \mu \mathrm{g} \mathrm{m}^{-3}$ to $230.4 \mu \mathrm{g} \mathrm{m}^{-3}$ for $\mathrm{PM}_{2.5}$ in Korhogo and in Abidjan, from $38.1 \mu \mathrm{g} \mathrm{m}^{-3}$ to $160.4 \mu \mathrm{g} \mathrm{m}^{-3}$ for $\mathrm{PM}_{10}$ and from $23.8 \mu \mathrm{g} \mathrm{m}^{-3}$ to $113.4 \mu \mathrm{g} \mathrm{m}^{-3}$ for $\mathrm{PM}_{2.5}$. The mean standard deviations of measured concentrations are of $89 \mu \mathrm{g} \mathrm{m}^{-3}$ and $23.5 \mu \mathrm{g} \mathrm{m}^{-3}$ for $\mathrm{PM}_{10}$ and of $41.5 \mu \mathrm{g} \mathrm{m}^{-3}$ and $17.9 \mu \mathrm{g} \mathrm{m}^{-3}$ for $\mathrm{PM}_{2.5}$ respectively in Korhogo and Abidjan. The standard deviation values are lower in Abidjan compared to Korhogo, which shows a greater variability in the latter. The maximum concentrations in Korhogo are respectively more than 3 to 5 times higher than in Abidjan whereas the minimum are 2 to 3 times higher. As already mentioned, this may be explained by additional aerosol sources occurring in Korhogo such as dust aerosol coming from northern African areas and/or from unpaved roads and the 2 -wheel emissions.

Table 2 presents the daily concentrations measured in African urban areas by this study, compared to literature results for Sub-Saharan Africa. $\mathrm{PM}_{2.5}$ concentrations measured in this study are lower than those measured with the individual exposures of Xu et al. (2019) in Abidjan. Personal exposure measurements are generally closer to the emission sources than our sites.

The PM 10 measurements performed by Ana et al. (2014) from January to March 2008 in Ibadan (Nigeria) are on the same order of magnitude as the concentrations measured at Korhogo in January 2019. These $\mathrm{PM}_{10}$ concentration levels are characteristic of the dry season in West Africa. For the same period of the year, Antonel and Chowdhury (2014) found lower $\mathrm{PM}_{10}$ concentrations $\left(105 \mu \mathrm{g} \mathrm{m}^{-3}\right.$ ) in Bafossam (Cameroon), which is further south, in a forest area, therefore less exposed to dust. Furthermore, the results obtained by Dionisio et al. (2010) showed that concentrations in low-income areas are higher than in high-income areas in Accra, which agrees with the results of this study. Finally, the ranges of concentrations obtained at Korhogo (in Tables S3 and S4) and Abidjan (in Tables S7 and S8) measurement sites are on the same order of magnitude as those obtained in other studies carried out in Sub-Saharan Africa. Values from other studies conducted in Africa are presented in Table S9 and agree very well with the results of this study. 
Table 2. Comparison between $\mathrm{PM}_{10}$ and $\mathrm{PM}_{2.5}$ daily concentrations obtained in this study and other studies Sub-Saharan Africa.

\begin{tabular}{|c|c|c|c|c|c|}
\hline City, Country & Site characteristic & Samplings period & $\begin{array}{l}\mathrm{PM}_{2.5} \\
\left(\mu \mathrm{g} \mathrm{m}^{-3}\right)\end{array}$ & $\begin{array}{l}\mathrm{PM}_{10} \\
\left(\mu \mathrm{g} \mathrm{m}^{-3}\right)\end{array}$ & Reference \\
\hline Korhogo, Cote d'Ivoire & 14 urban sites & Jan-2019 & $54.3-218$ & $212.2-534.7$ & This study \\
\hline Abidjan, Cote d'Ivoire & 20 urban sites & Jan. to Feb-2019 & $23.8-113.4$ & $38.1-160.4$ & \\
\hline \multirow[t]{2}{*}{ Abidjan, Cote d'Ivoire } & Urban $\left(\mathrm{WB}^{a}\right)$ & Jan. and July-2016 & 494.3 & - & Xu et al. (2019) \\
\hline & Urban $\left(D^{b}\right)$ & & 358.8 & - & \\
\hline Cotonou, Benin & Traffic & & 335.1 & - & \\
\hline \multirow[t]{2}{*}{ Accra, Ghana } & Traffic-highest SES ${ }^{c}$ & 2007 & 21 & 49 & Dionisio et al. (2010) \\
\hline & Traffic-lowest SES & & 39 & 96 & \\
\hline Dakar, Senegal & Urban & Jun-2008 to Jun-2009 & 44.4 & - & Doumbia et al. (2012) \\
\hline \multirow[t]{4}{*}{ Ibadan, Nigeria } & Commercial area & Jan. and Mar-2008 & - & 422.3 & Ana et al. (2014) \\
\hline & Traffic & & - & 328.1 & \\
\hline & Industrial & & - & 319.7 & \\
\hline & Residential & & - & 257.4 & \\
\hline Bamako, Mali & Urban & $\begin{array}{l}\text { Sep. to Oct-2012 and } \\
\text { Jul-2013 }\end{array}$ & 43 & 210 & Garrison et al. (2014) \\
\hline Ouagadougou, Burkina & Urban & Nov. to Dec-2017 & 86 & - & Boman et al. (2009) \\
\hline Faso & Suburban & & 69 & - & \\
\hline Accra, Ghana & Traffic & Jun. to Jul-2006 & 27.4 & 71.8 & Arku et al. (2008) \\
\hline Bafoussam, Cameroun & Urban & Jan. to Mar-2012 & 67 & 105 & Antonel and \\
\hline Bamenda, Cameroun & & & 132 & 141 & Chowdhury (2014) \\
\hline Yaoundé, Cameroun & & & 49 & 65 & \\
\hline Libreville, Gabon & Urban & Jun. to Jul-2015 & 35.8 & - & Ngo et al. (2019) \\
\hline Port-Gentil, Gabon & & & 60.9 & - & \\
\hline
\end{tabular}

$\left({ }^{a}\right)$ WB: Waste Burning; $\left({ }^{b}\right)$ DF: Domestic Fire; $\left({ }^{c}\right)$ Social Economic Status; "-": not measured.

\section{CONCLUSIONS}

This study provides an assessment of air quality in the cities of Korhogo and Abidjan in Cote d'Ivoire by proposing for the first time to our knowledge, spatial variation maps of $\mathrm{PM}_{10}$ and $\mathrm{PM}_{2.5}$ concentrations. It is part of the objectives of the PASMU project, which aims to characterize urban air pollution and its impact on health in Cote d'Ivoire.

The use of low-cost sensors at 14 sites in Korhogo and 20 in Abidjan resulted in daily average $\mathrm{PM}_{10}$ concentrations ranging from $212.2 \mu \mathrm{g} \mathrm{m}^{-3}$ to $534.7 \mu \mathrm{g} \mathrm{m}^{-3}$ in Korhogo and from $38.1 \mu \mathrm{g} \mathrm{m}^{-3}$ to $160.4 \mu \mathrm{g} \mathrm{m}^{-3}$ in Abidjan. $\mathrm{PM}_{2.5}$ concentrations range from $57.4 \mu \mathrm{g} \mathrm{m}^{-3}$ to $230.4 \mu \mathrm{g} \mathrm{m}^{-3}$ and from $23.8 \mu \mathrm{g} \mathrm{m}^{-3}$ to $113.4 \mu \mathrm{g} \mathrm{m}^{-3}$ in Korhogo and Abidjan respectively.

The spatial variation maps obtained through the application of GIS in Korhogo show that the high activity areas (market and national bus station) have higher $\mathrm{PM}_{10}$ and $\mathrm{PM}_{2.5}$ concentration levels than other areas. Our study also highlights that the relative contribution of $\mathrm{PM}_{2.5}$ to $\mathrm{PM}_{10}$ is very different in Korhogo and Abidjan, varying from 50 to $100 \%$ in Abidjan, while 20 to $50 \%$ in Korhogo. In Abidjan, a difference between the concentrations is observed in high- and lowincome neighborhoods, with higher concentration levels in low- and middle-income neighborhoods. One likely reason is that, high-income areas have better services (roads, waste collection, ...), and also use less polluting cooking methods (e.g., gas). This result can be also explained by the status of the city: (1) in Korhogo, the higher presence of coarse particles is due to anthropogenic (road dust resuspension) and natural sources (desert dust transport); (2) Abidjan is an economic capital with a higher population density, road traffic and generally a higher activity density than in Korhogo. The concentrations measured in this work are comparable to previous studies conducted in Abidjan and in Africa.

In conclusion, this study indicates that this simple and reproductive method provides a quality assessment of particulate pollution at the city level. Note that this method could be also used for other purposes such as performing a quick assessment of the impact of a new industrial unit or infrastructure on the surrounding air quality. Finally, the original results obtained on urban 
particulate pollution in Korhogo and Abidjan, relative contribution of fine particle to coarse and daily variations of PM concentrations will be very useful for urban modelling in West African cities.

\section{ACKNOWLEDGEMENTS}

This project is funded by the Education and Research Ministry of Cote d'Ivoire, as part of the Debt Reduction-Development Contracts (C2Ds) managed by Institut de Recherche pour le Développement (IRD). The authors would like to thank AMRUGE-Cl scholarship (Appui à la Modernisation et à la Réforme des Universités et Grandes Ecoles de Côte d'Ivoire).

Special thanks to the populations and some institutions in Abidjan and Korhogo for hosting the measuring equipment.

The authors acknowledge the contribution of all the members of the Aerosols and Pollution team in Abidjan and Korhogo to this study, specially Doctor Alima Dajuma, and more generally the Laboratoire de Physique de l'Atmosphère et de Mécanique des Fluides (LAPA-MF, Côte d'Ivoire), now Laboratoire des Sciences de la Matière, de l'Environnement et de l'énergie Solaire and Laboratoire d'Aérologie (LA, France).

\section{DISCLAIMER}

The authors decline any commercial link with the companies producing equipment or software used in this study.

\section{SUPPLEMENTARY MATERIAL}

Supplementary data associated with this article can be found in the online version at https://doi.org/10.4209/aaqr.2020.05.0201

\section{REFERENCES}

Adame, J.A., Hernández-Ceballos, M.Á., Sorribas, M., Lozano, A. and Morena, B.A.D.I. (2014). Weekend-Weekday effect assessment for $\mathrm{O}_{3}, \mathrm{NO}_{x}, \mathrm{CO}$ and $\mathrm{PM}_{10}$ in Andalusia, Spain (20032008). Aerosol Air Qual. Res. 14, 1862-1874. https://doi.org/10.4209/aaqr.2014.02.0026

Adon, A.J. (2019). Évaluation de l'impact sur la santé de l'aérosol de combustion pour différentes sources urbaines en Afrique de l'Ouest en saison sèche et humide : caractérisation physicochimique et toxicologique. Université Toulouse III - Paul Sabatier, Toulouse.

Adon, A.J., Liousse, C., Doumbia, E.T., Baeza-Squiban, A., Cachier, H., Léon, J.F., Yoboue, V., Akpo, A.B., Galy-Lacaux, C., Zoutien, C., Xu, H., Gardrat, E., Keita, S. (2020). Physico-chemical characterization of urban aerosols from specific combustion sources in West Africa at Abidjan in Côte d'Ivoire and Cotonou in Benin in the frame of DACCIWA program. Atmos. Chem. Phys. 20, 5327-5354. https://doi.org/10.5194/acp-20-5327-2020

AGEROUTE (2020). Etendue du Réseau Routier Ivoirien. https://ageroute.ci/index.php/gestiondu-reseau/reseau-routier/repartition-cartographie (accessed: 14 March 2020).

Ana, G., Odeshi, T., Sridhar, M., Ige, M. (2014). Outdoor respirable particulate matter and the lung function status of residents of selected communities in Ibadan, Nigeria. Perspect. Public Health 134, 169-175. https://doi.org/10.1177/1757913913494152

Antonel, J., Chowdhury, Z. (2014). Measuring ambient particulate matter in three cities in Cameroon, Africa. Atmos. Environ. 95, 344-354. https://doi.org/10.1016/j.atmosenv.2014.06. 053

Arku, R.E., Vallarino, J., Dionisio, K.L., Willis, R., Choi, H., Wilson, J.G., Hemphill, C., Agyei-Mensah, S., Spengler, J.D., Ezzati, M. (2008). Characterizing air pollution in two low-income neighborhoods in Accra, Ghana. Sci. Total Environ. 402, 217-231. https://doi.org/10.1016/j.sc itotenv.2008.04.042

Bahino, J., Yoboué, V., Galy-Lacaux, C., Adon, M., Akpo, A., Keita, S., Liousse, C., Gardrat, E., Chiron, 
C., Ossohou, M., Gnamien, S., Djossou, J. (2018). A pilot study of gaseous pollutants' measurement $\left(\mathrm{NO}_{2}, \mathrm{SO}_{2}, \mathrm{NH}_{3}, \mathrm{HNO}_{3}\right.$ and $\left.\mathrm{O}_{3}\right)$ in Abidjan, Côte d'Ivoire: contribution to an overview of gaseous pollution in African cities. Atmos. Chem. Phys. 18, 5173-5198. https://doi.org/10.5194/acp-18-5173-2018

Boman, J., Lindén, J., Thorsson, S., Holmer, B., Eliasson, I. (2009). A tentative study of urban and suburban fine particles ( $\left.\mathrm{PM}_{2.5}\right)$ collected in Ouagadougou, Burkina Faso. X-Ray Spectrom. 38, 354-362. https://doi.org/10.1002/xrs.1173

Chai, T., Draxler, R.R. (2014). Root mean square error (RMSE) or mean absolute error (MAE) Arguments against avoiding RMSE in the literature. Geosci. Model. Dev. 7, 1247-1250. https://doi.org/10.5194/gmd-7-1247-2014

Chatterjee, A., Engelen, R.J., Kawa, S.R., Sweeney, C., Michalak, A.M. (2013). Background error covariance estimation for atmospheric $\mathrm{CO}_{2}$ data assimilation. J. Geophys. Res. 118, 1014010154. https://doi.org/10.1002/jgrd.50654

Cheng, Y.H., Li, Y.S. (2010). Influences of traffic emissions and meteorological conditions on ambient $\mathrm{PM}_{10}$ and $\mathrm{PM}_{2.5}$ levels at a highway toll station. Aerosol Air Qual. Res. 10, 456-462. https://doi.org/10.4209/aaqr.2010.04.0025

Clements, A.L., Griswold, W.G., Rs, A., Johnston, J.E., Herting, M.M., Thorson, J., Collier-Oxandale, A., Hannigan, M. (2017). Low-cost air quality monitoring tools: From research to practice (A workshop summary). Sensors 17, 2478. https://doi.org/10.3390/s17112478

Cohen, A.J., Ross Anderson, H., Ostro, B., Pandey, K.D., Krzyzanowski, M., Künzli, N., Gutschmidt, K., Pope, A., Romieu, I., Samet, J.M., Smith, K. (2005). The global burden of disease due to outdoor air pollution. J. Toxicol. Environ. Health Part A 68, 1301-1307. https://doi.org/10.108 0/15287390590936166

Dieme, D., Cabral-Ndior, M., Garçon, G., Verdin, A., Billet, S., Cazier, F., Courcot, D., Diouf, A., Shirali, P. (2012). Relationship between physicochemical characterization and toxicity of fine particulate matter $\left(\mathrm{PM}_{2.5}\right)$ collected in Dakar city (Senegal). Environ. Res. 113, 1-13. https://doi.org/10.1016/j.envres.2011.11.009

Dionisio, K.L., Rooney, M.S., Arku, R.E., Friedman, A.B., Hughes, A.F., Vallarino, J., Agyei-Mensah, S., Spengler, J.D., Ezzati, M. (2010). Within-neighborhood patterns and sources of particle pollution: Mobile monitoring and geographic information system analysis in four communities in Accra, Ghana. Environ. Health Perspect. 118, 607-613. https://doi.org/10.1289/ehp.0901365

Djossou, J. (2018). Analyse de la pollution atmosphérique en zones urbaines en Côte d'Ivoire et au Bénin dans le cadre du programme DACCIWA: Pollution particulaire.

Djossou, J., Léon, J.F., Akpo, A.B., Liousse, C., Yoboué, V., Bedou, M., Bodjrenou, M., Chiron, C., Galy-Lacaux, C., Gardrat, E., Abbey, M., Keita, S., Bahino, J., Touré N’Datchoh, E., Ossohou, M., Awanou, C.N. (2018). Mass concentration, optical depth and carbon composition of particulate matter in the major southern West African cities of Cotonou (Benin) and Abidjan (Côte d'Ivoire). Atmospheric Chemistry and Physics 18, 6275-6291. https://doi.org/10.5194/acp-18-62752018

Doumbia, E.H.T., Liousse, C., Galy-Lacaux, C., Ndiaye, S.A., Diop, B., Ouafo, M., Assamoi, E.M. Gardrat, E., Castera, P., Rosset, R., Akpo, A., Sigha, L. (2012). Real time black carbon measurements in West and Central Africa urban sites. Atmos. Environ. 54, 529-537. https://doi.org/10.1016/j.atmosenv.2012.02.005

Egondi, T., Muindi, K., Kyobutungi, C., Gatari, M., Rocklöv, J. (2016). Measuring exposure levels of inhalable airborne particles $\left(\mathrm{PM}_{2.5}\right)$ in two socially deprived areas of Nairobi, Kenya. Environ. Res. 148, 500-506. https://doi.org/10.1016/j.envres.2016.03.018

Garrison, V.H., Majewski, M.S., Konde, L., Wolf, R.E., Otto, R.D., Tsuneoka, Y. (2014). Inhalable desert dust, urban emissions, and potentially biotoxic metals in urban Saharan-Sahelian air. Sci. Total Environ. 500-501, 383-394. https://doi.org/10.1016/j.scitotenv.2014.08.106

Gualtieri, G., Toscano, P., Crisci, A., Di Lonardo, S., Tartaglia, M., Vagnoli, C., Zaldei, A., Gioli, B. (2015). Influence of road traffic, residential heating and meteorological conditions on $\mathrm{PM}_{10}$ concentrations during air pollution critical episodes. Environ. Sci. Pollut. Res. 22, 19027-19038. https://doi.org/10.1007/s11356-015-5099-x

Jeannée, N., Mosqueron, L., Nedellec, V., Elichegaray, C., Bouallala, S., Desqueyroux, H., Guillaume, B., Liousse, C., Lagache, R. (2006). Évaluation de l'exposition en zones urbaines à la pollution atmosphérique: Méthodes existantes et application aux $\mathrm{PM}_{10}$ en France métropolitaine. Pollut. 
Atmos. 190, 197-207. https://doi.org/10.4267/pollution-atmospherique.1517

Jerez, S., Montavez, J.P., Jimenez-Guerrero, P., Gomez-Navarro, J.J., Lorente-Plazas, R., Zorita, E. (2013). A multi-physics ensemble of present-day climate regional simulations over the Iberian Peninsula. Clim. Dyn. 40, 3023-3046. https://doi.org/10.1007/s00382-012-1539-1

Kalisa, E., Archer, S., Nagato, E., Bizuru, E., Lee, K., Tang, N., Pointing, S., Hayakawa, K., LacapBugler, D. (2019). Chemical and biological components of urban aerosols in Africa: Current status and knowledge gaps. Int. J. Environ. Res. Public Health 16, 941. https://doi.org/10.3390/ ijerph16060941

Keita, S., Liousse, C., Assamoi, E.M., Doumbia, E.H.T., Toure, N., Elguindi, N., Granier, C., Yoboue, V. (2020). African Anthropogenic Emissions Inventory for gases and particles from 1990 to 2015. Earth Syst. Sci. Data Discuss. https://doi.org/10.5194/essd-2020-328

Kirenga, B., Meng, Q., van Gemert, F., Aanyu-Tukamuhebwa, H., Chavannes, N., Katamba, A., Obai, G., Molen, T., Schwander, S., Mohsenin, V. (2015). The state of ambient air quality in two ugandan cities: A pilot cross-sectional spatial assessment. Int. J. Environ. Res. Public Health 12, 8075-8091. https://doi.org/10.3390/ijerph120708075

Liousse, C., Assamoi, E., Criqui, P., Granier, C., Rosset, R. (2014). Explosive growth in African combustion emissions from 2005 to 2030. Environ. Res. Lett. 9, 035003. https://doi.org/10.10 88/1748-9326/9/3/035003

Liousse, C., Toure, N., Roblou, L., Baeza-Squiban, A., Annesi-Maesano, I. (2019). Dynamics-aerosolchemistry-cloud interactions in West Africa - Inflammatory risk regional maps (No. D2.5).

McKeen, S., Wilczak, J., Grell, G., Djalalova, I., Peckham, S., Hsie, E.Y., Gong, W., Bouchet, V., Menard, S., Moffet, R., McHenry, J., McQueen, J., Tang, Y., Carmichael, G.R., Pagowski, M., Chan, A., Dye, T., Frost, G., Lee, P., Mathur, R. (2005). Assessment of an ensemble of seven real-time ozone forecasts over eastern North America during the summer of 2004. J. Geophys. Res. 110, D21307. https://doi.org/10.1029/2005JD005858

MCLAU (2015). Le projet de développement du Schema Directeur des transports urbains du grand Abidjan (Rapport Final No. Volume III). Ministère de la Construction, du Logement, de l'Assainissement et de l'Urbanisme.

Ministry of Transports (2017). Ministère des Transports. http://www.transports.gouv.ci/ac tualites/importation-et-exploitation-des-vehicules-importes-le-gouvernement-adopte-deuxdecrets (accessed: 163 March 2020).

Murray, C.J.L., Vos, T., Lozano, R., Naghavi, M., Flaxman, A.D., Michaud, C., Ezzati, M., Shibuya, K., Salomon, J.A., Abdalla, S., Aboyans, V., Abraham, J., Ackerman, I., Aggarwal, R., Ahn, S.Y., Ali, M.K., AlMazroa, M.A., Alvarado, M., Anderson, H.R., Anderson, L.M., ... Lopez, A.D. (2012). Disability-adjusted life years (DALYs) for 291 diseases and injuries in 21 regions, 1990-2010: a systematic analysis for the Global Burden of Disease Study 2010. Lancet 380, 2197-2223. https://doi.org/10.1016/S0140-6736(12)61689-4

Ngo, N.S., Asseko, S.V.J., Ebanega, M.O., Allo'o Allo'o, S.M., Hystad, P. (2019). The relationship among $\mathrm{PM}_{2.5}$, traffic emissions, and socioeconomic status: Evidence from Gabon using low-cost, portable air quality monitors. Transp. Res. Part D 68, 2-9. https://doi.org/10.1016/j.trd.2018.01.029

Nouaceur, Z., Murarescu, O. (2020). Rainfall variability and trend analysis of rainfall in West Africa (Senegal, Mauritania, Burkina Faso). Water 12, 1754. https://doi.org/10.3390/w12061754

RGPH (2014). Indicateurs Démographiques. Institut National de la Statistique.

Rivera-González, L.O., Zhang, Z., Sánchez, B.N., Zhang, K., Brown, D.G., Rojas-Bracho, L., OsornioVargas, A., Vadillo-Ortega, F., O'Neill, M.S. (2015). An assessment of air pollutant exposure methods in Mexico City, Mexico. J. Air Waste Manage. Assoc. 65, 581-591. https://doi.org/10. 1080/10962247.2015.1020974

Savage, N.H., Agnew, P., Davis, L.S., Ordóñez, C., Thorpe, R., Johnson, C.E., O'Connor, F.M., Dalvi, M. (2013). Air quality modelling using the Met Office Unified Model (AQUM OS24-26): Model description and initial evaluation. Geosci. Model Dev. 6, 353-372. https://doi.org/10.5194/gmd6-353-2013

Shukla, K., Kumar, P., Mann, G.S., Khare, M. (2020). Mapping spatial distribution of particulate matter using Kriging and Inverse Distance Weighting at supersites of megacity Delhi. Sustainable Cities Soc 54, 101997. https://doi.org/10.1016/j.scs.2019.101997

Stern, D.I., van Dijk, J. (2017). Economic growth and global particulate pollution concentrations. Clim. Change 142, 391-406. https://doi.org/10.1007/s10584-017-1955-7 
Taylor, M.H., Losch, M., Wenzel, M., Schröter, J. (2013). On the Sensitivity of Field Reconstruction and Prediction Using Empirical Orthogonal Functions Derived from Gappy Data. J. Clim. 26, 9194-9205. https://doi.org/10.1175/JCLI-D-13-00089.1

Val, S., Liousse, C., Doumbia, E.H.T., Galy-Lacaux, C., Cachier, H., Marchand, N., Badel, A., Gardrat, E., Sylvestre, A., Baeza-Squiban, A. (2013). Physico-chemical characterization of African urban aerosols (Bamako in Mali and Dakar in Senegal) and their toxic effects in human bronchial epithelial cells: Description of a worrying situation. Part. Fibre Toxicol. 10, 10. https://doi.org/ 10.1186/1743-8977-10-10

Wang, Y., Li, J., Jing, H., Zhang, Q., Jiang, J., Biswas, P. (2015). Laboratory evaluation and calibration of three low-cost particle sensors for particulate matter measurement. Aerosol Sci. Technol. 49, 1063-1077. https://doi.org/10.1080/02786826.2015.1100710

Xu, H., Léon, J.F., Liousse, C., Guinot, B., Yoboué, V., Akpo, A.B., Adon, J., Ho, K.F., Ho, S.S.H., Li, L., Gardrat, E., Shen, Z., Cao, J. (2019). Personal exposure to PM $_{2.5}$ emitted from typical anthropogenic sources in southern West Africa: chemical characteristics and associated health risks. Atmos. Chem. Phys. 19, 6637-6657. https://doi.org/10.5194/acp-19-6637-2019

Zamri, M., Ismail, M., Kim, Y. (2012). Mapping the Spatial Distribution of Criteria Air Pollutants in Peninsular Malaysia Using Geographical Information System (GIS), in: Khare, M. (Ed.), Air pollution - Monitoring, modelling and health. InTech. https://doi.org/10.5772/32902

Zuidema, C., Stebounova, L.V., Sousan, S., Thomas, G., Koehler, K., Peters, T.M. (2019). Sources of error and variability in particulate matter sensor network measurements. J. Occup. Environ. Hyg. 16, 564-574. https://doi.org/10.1080/15459624.2019.1628965 